\title{
Social Practice Participants in the Independent Graduation in the Family Hope Program (PKH)
}

\author{
David Prima Darwin ${ }^{1}$, Azwar ${ }^{2}$, Indraddin ${ }^{3}$ \\ ${ }^{1,2,3}$ Program Studi Magister Sosiologi, Fakultas IImu Sosial dan IImu Politik, Universitas \\ Andalas, Indonesia \\ Email: davidprima.darwin@gmail.com
}

\begin{abstract}
This study aims to describe the social practice of independent graduation participants in the Family Hope Program (PKH) in Nagari Batu Balang, Harau District, Lima Puluh Kota District. This study uses a descriptive-based qualitative approach with the informants selected using a purposive sampling technique. In collecting data used in-depth interview techniques, involved observation, and documentation studies. The results of this study indicate that habitus plays a role in encouraging $\mathrm{PKH}$ participants in independent graduation from persistence in working, having a sense of shame, discipline, frugal, and honest. The forms of capital owned by PKH participants in independent graduation are social capital, economic capital, cultural capital, and symbolic capital. The form of the PKH arena that plays PKH participants in independent graduation is to hold monthly meetings to add insight, monthly meetings as a first step to starting a household business, conducting health checks at the Polindes and Puskesmas, paying attention to the presence of children at school, saving to open a household business, dare to open a household business, and use the land around the neighbourhood to grow vegetables and medicinal plants.
\end{abstract}

Keywords: Social Practice, Family Hope Program, Independent Graduation.

\section{A. INTRODUCTION}

Poverty is an interesting social problem to continue to study scientifically the problem so that it can change the lives of poor people for the better. The Family Hope Program called $\mathrm{PKH}$ is a conditional social assistance program for families or poor and vulnerable people who are registered in an integrated data handling program for the poor, then processed by the Social Welfare Data and Information Center, and subsequently designated as PKH beneficiary families by the Ministry of Social Affairs (Permensos, 2018).

One indicator of the success of the PKH program is the presence of Graduated participants. Graduation in PKH can be categorized as Natural Graduation, Economic Able Graduation and Independent or Voluntary Graduation. Natural graduation is the end of the membership period due to non-fulfilment of the criteria for membership or there are no more $\mathrm{PKH}$ components as a condition for receiving $\mathrm{PKH}$ assistance. Graduation increased economically is the end of the PKH membership period due to the economic improvement of PKH participants. Independent or voluntary Graduation is a Graduation caused by personal awareness by $\mathrm{PKH}$ participants not to receive $\mathrm{PKH}$ 
assistance anymore (RI Ministry of Social Affairs Letter Number: 384 / LJS.JSK.TU / 03/2017 concerning PKPM KPM Graduation Report).

The Ministry of Social Affairs of the Republic of Indonesia is very focused on the PKH independent graduation effort. Looking at the number of KPM PKH that have graduated independently increasing from year to year. In 2017 the number of independent prosperous KPM was 230,351 families with a percentage of $3.69 \%$ of the total existing participants of 6,228,810 families. Then in 2018, there was independent graduation of 621,789 families with a percentage of $6.21 \%$ of the total participants of 10,000,000 families (https://mediaindonesia.com, accessed on Tuesday, July 2, 2019). However, with the national increase in independent graduation data, in West Sumatra, the Independent Graduation Province still occurred in 2019 as many as 465 people or 0.25 per cent of the total 181,807 recipients of PKH assistance in West Sumatra Province. Therefore it is very important to conduct research to help the government to increase independent graduation in West Sumatra Province, especially in Lima Puluh Kota District.

This independent graduation is very interesting to study further compared to the other two graduation categories because Islamiah graduation to get out of $\mathrm{PKH}$ membership needs to wait for the time out of the aid component, and Graduate is able to economically wait for the participant's economic growth until it is declared capable by the program, while the independent graduation it was a conscious decision from PKH participants to opt-out on their own without waiting for components to run out and be economically capable.

For Bourdieu, that to overcome the absurd position between the individual and the community there needs to be a social construction process that is used by actors to perceive, think about, and construct structures (Ritzer, 2016). For Bourdieu, that what is understood or obtained by the actor is displayed, and what is displayed by the actor is his understanding. This is what he calls the Social Practice. Social Practice seen by Pirre Bourdieu uses the Concept of Habitus, Capital, and Social Arena. Habitus is a social value that is lived by the individual created by a long, internalized socialization process that is internalized and settled within itself so that it becomes a way of thinking and behaving in action. Habitus was adopted through nurture and education because all actions taken by humans that occur in the social arena are arenas for the struggle of all resources owned by individuals. Therefore, individuals always try to distinguish themselves from others and obtain useful or valuable capital in the arena (Harker et al., 2009).

Capital for Bourdieu is the concentration of power or available resources. Capital is a specific force that operates within the Arena. Each domain or arena requires a person to have special capital in order to live well and survive in it. This capital must be in the arena or domain so that the arena can have meaning or meaning. Likewise, for PKH participants, PKH participants should have been aware that when they were in the 
PKH Arena, they realized that they had a lot of capital such as social capital, capital so that they could quickly succeed in fighting and fighting in the PKH arena to achieve the highest status, namely Independent Graduation, and vice versa when the PKH KPM who is not aware of it has a lot of capital in carrying out an action on the PKH Arena, then he is likely to survive the Transition status. This capital should be realized there and owned by individuals in their social environment so that it allows people to control themselves and others (Ritzer, 2012).

Therefore, to prove it, it is important to conduct research in order to get answers to How the Social Practices of the Graduation Mandiri Participants Family Hope Program. This study aims to describe the social practices of independent graduation participants in the Harapan Families Program in Nagari Batu Balang, Harau District, Lima Puluh Kota.

\section{B. METHODOLOGY}

This research was conducted in Nagari Batu Balang, Harau Subdistrict, Lima Puluh City, West Sumatra Province, using descriptive qualitative methods. There were 10 informants chosen using a purposive sampling technique. In collecting data used indepth interview techniques, involved observation, and document study. The informants in this study the authors grouped two categories of informants namely observer informants and perpetrator informants (Afrizal (2014). The informant actors in this study were PKH Graduasi Mandiri Participants in 2019 with the 2013 membership period due to the successful use of PKH assistance in Nagari Batu Balang, Harau District Observer informants in this study were the Parents, PKH Companion in Nagari Batu Balang, Harau District, Wali Nagari Batu Balang.

Data collection in this research was carried out through observation, interviews and documentation studies. Analysis of the data in this writing is done qualitatively which is more emphasized on qualitative interpretative. Data obtained in the field, both in the form of primary data and secondary data are recorded with field notes.

\section{RESULT AND DISCUSSION}

\section{Habits who Role in Encouraging Independent Graduation Participants in the PKH}

Habits that play a role in encouraging independent graduation participants in the PKH are as follows:

a. Tenacity at Work

Perseverance in working for PKH participants in independent graduation is a long process that goes through in each session of his life. For example, since childhood PKH participants at independent graduation have been trained to carry out an activity that has responsibilities. The activity is in the form of daily household activities such as cooking rice for family dinners, washing dishes, and cleaning the house. This process is 
passed continuously by independent graduation participants so that the habit of working and carrying out tasks as a child becomes an inseparable value. in themselves. In adolescence they were given more burdens by their parents by asking them to go to the rice fields, gambier gardens, look for grass for goats, look for firewood in the hills and receive wages from other people in the rubber plantation. But there are also those who work to help parents produce Rubik special food. Rubik is a type of food made from cassava which is boiled and shaped in various forms. They work according to the conditions and energy they have, meaning the work done is not too heavy. For example to the paddy field that is only done to clean the grass around the rice groves (basiang), if they go to the garden to clean the grass around the gambier plant, and when receiving wages in the rubber garden as a mentor that is taking notes for each yield from the rubber harvest. During this working life, it has become a basic attitude that is repeatedly carried out by independent graduation participants. He acknowledged this attitude, it is difficult to disappear and go away within themselves, even when they are not working they feel something is missing, even their physical body aches due to not working.

b. High Shyness

For PKH participants who do independent graduation, shame is one that makes them choose to come out as people who receive PKH assistance. Since childhood, they have been inculcated about the values of community life, neighbours, family, religious values, and social culture. For example, when there are guests coming, the host must respect and serve drinks and food. When there is nothing that cannot be eaten, the host will make every effort to provide food. One way to borrow is from relatives or closest neighbours, which can be processed into food such as rice. This was conveyed by Informant "RB" biological mother of "EE". According to "RB", there was a guest who came to his house and happened to run out of rice so it was not enough to be cooked, then he told his son to borrow rice from neighbours but through the back door. This means that there is an effort from "RB" to not convey how the actual conditions experienced at that time, the important thing is the guest can enjoy the food provided. More precisely as bitter as the life he lived, he did not want others to know. Then different things were experienced by other PKH participants who graduated independently during their school days.

PKH participant who independent graduation "SP" when there were no snacks given by his parents to school then he asked his mother to make food that he could sell to his school friends so he could have money and could be used for snacks. This indicates that the recipient is no better than trying himself and enjoying the results of the effort. When someone does not want to accept, he has maintained the dignity of himself and his family. although the methods taken by selling in schools that are important to him the business is lawful and does not burden other people. More importantly, the value of entrepreneurship has been embedded in the child from an 
early age. Then another different way of investing value was experienced by "WD" in the time of his girl where he did not like it when his yard was dirty like grass turning green and trash scattered in his yard. For "WD" a girl must look after their home, both inside and outside the house like the yard. This was done so that there is no negative view of children such as lazy, dirty, and flustered. That assessment will bring shame to the family and will be able to influence interactions in the community. Then Widiawati's experience also shows that there is a thing that must be maintained, that is the house as a gathering place for a family.

\section{c. Discipline}

In disciplinary habits, there are at least some experiences that are passed by independent graduation informants. Every experience that is passed is different but has the same meaning and purpose. The purpose and meaning go hand in hand from the process of experience that is implanted consciously or unconsciously by parents and children. The forms of disciplinary activities that they get differ. Where in their childhood when elementary school they were familiarized with waking up in the morning alone, then doing the morning prayer, bathing alone without the help of his parents then having breakfast before going to school with his friends. When they come home from school, they do their schoolwork or (Homework) and then carry out play activities with their friends. After completing play activities then they go home according to the time set by their parents such as "WD" at three o'clock in the afternoon must be at home to help his mother's work and repeat the reading of the Koran obtained in the mosque the day before in preparation for the Koran at night. Then a different form of disciplinary value is obtained by "EE", where at four o'clock in the afternoon he must be at his home. When he does not go home at the time set by his parents, then he will be picked up by his parents where he is playing, when he goes to make schoolwork or homework (homework) to his friend's place from junior high school to senior high school accompanied by someone the old. Then until this "EE" determines his life companion is also sought by his parents. Then he agreed without rejecting the search for his parents. Then a different discipline value was also obtained by another PKH at independent graduation participant, "AY", where when there was incomplete work done, the mother would ask her child to finish the work until completion. In fact, he even got hit using a wooden stick with his parents.

Then other forms of discipline differ slightly from that obtained by "YRS" that is when he comes home from school, he does the dishes, sweeps the house, and loves to eat goats and after playing he goes to find goatgrass. Where every job given to him is completed first before he goes to play to his friend's house or to buts. Then the other forms of discipline that get by "SP" are also slightly different from the others. Where he was from childhood until his teenage years when he wanted to travel anywhere, always asking permission from both parents. Then he was given or not given his daily spending money with parents, but he still went to school. Then, when sunset comes all 
the doors of the house must be closed, and no one can open a single window of his house. For them, the value of this discipline made an impression on him even though they were married.

\section{d. Lifesaver}

The frugal lifestyle is instilled since childhood in different ways. As experienced by PKH participants who were Graduated Mandiri. Where they have been accustomed by their parents to save from the rest of their allowance every day even though only five dollars of the remaining daily spending money. They save by using a piggy bank such as Poriang, which is bamboo that is cut, then given a hole in itself, then there is someone who saves from a decorated clay piggy bank as beautiful as possible. This has been instilled since they were young. Then in junior high and senior high school, they familiarized themselves with the weekly social gathering they called julo-julo. Their proceeds from the social gathering are used to buy goats and other necessities. Different things experienced by "EE" where he was during elementary to high school when eating activities at home took place. he is very guarding the food on the plate to be eaten until it runs out and he will be angry at family members who live above the house if there is food leftover. Then when in cooking he is very good at arranging cooked chilli. Usually, the food to be used a day is made into two days by using a variety of chilli mixtures. Then different forms of thrifty behaviour are also experienced by "WD", where when he is not given money to spend with his parents he asks food packages to be wrapped namely rice to be brought to school.

e. Behave Honestly

Another important social basic value held by $\mathrm{PKH}$ participants in independent graduation is honesty. The honest attitude possessed by $\mathrm{PKH}$ participants in independent graduation became the main capital in building relationships and social life, including in entrepreneurship. As experienced by Widiawati in childhood. Where he was given school spending money when the amount was set by the parents. When the amount is given is large because there is no pass, then the rest is returned to the parents. Because he will only spend how much has been determined by parents. Likewise, when asked by the old man shopping for an item, what is told, that's what he bought and no more than that. Meanwhile, the income of "WD" as a Mentaris in a rubber plantation was left entirely to his parents. The form of honesty experienced by "EE", is slightly different from the experience. Since elementary to high school, when he came home from school, he never stopped at his friend's house or any other place. If a man approaches him he will be passed on to his parents. Three other Graduation participants are accustomed to saving by parents. The savings come from the rest of the school allowance. When their allowance is excessive, they tell their parents that the rest of the allowance is included in their savings. If not put into savings, the money is handed over directly to their parents. But those among them, do not return to their 
parents but use the remaining allowance to shop when reciting Koran. Even so, what he did was still known by his parents.

\section{Capital that has a role in Encouraging Independent Graduation Participants in PKH}

The capital that plays a role in encouraging independent graduation participants at PKH is as follows:

\section{a. Social Capital}

For Bourdieu, this social capital is a valuable social relationship between people. This can be exemplified by some people who interact between classes in the social layer of society (Ritzer, 2016: 583). Participants in PKH Graduasi Mandiri like "EE" who have a clothing business now. He started a business by selling from house to house. The business activities that are driven are carried out patiently, and perseveringly until a fairly large number of consumers are formed. He is always awaited by people who want the products they sell. From the interactions that repeatedly make it trusted by the public or consumers. The trust was obtained from the process of maintaining good relations with relations continuously. He is very concerned about the quality of the products he sells so that trust can persist. When the network and trust had been obtained, that's where he set up a simple shop containing second-hand clothes worth selling. The average consumer who usually now goes to the store to shop.

Not much different experienced by the "YRS" who have Cricket Cultivation. The experience that "YRS" went through when he started his cultivation business from two cultivation sites, namely two boxes. Consumers who first bought crickets when starting a business were given bonuses in the form of excess crickets and low selling prices than the usual market. Usually, crickets that are sold are used for bird food, and for ornamental fish food. Then the person who used to buy crickets to jurmanelis told his friends in the community that the price of crickets in jurmanelis was cheap and a lot. Person-to-person promotion made him known as one of the producers of cricket cultivation in his area.

\section{b. Economic Capital}

Economic capital is a resource that can be a means of production and financial means. All types of capital are easy to use for all purposes and passed down from generation to generation (Halim, 2014). As experienced by $\mathrm{PKH}$ in independent graduation participants, namely "SP". Where he was when he was a teenager that is when middle school and high school had been accustomed to entrepreneurship by selling cakes, fruits in his garden to friends at school. In fact, he has been able to make his own traditional foods that can be marketed installs. The habit of selling as a child seemed to be the capital that made him able to survive until now. Because at this time the person concerned is still engaged in trading activities, selling basic necessities or daily needs of household needs at the location where he lives. Not much different 
experienced by other participants who have cricket cultivation. The experience that "YRS" went through when he started his cultivation business from two cultivation sites namely two boxes to become forty-three boxes produced more than five million per month.

\section{c. Cultural Capital}

Cultural capital is an overall intellectual qualification that can be produced through formal education and family inheritance, such as the ability to present themselves in public, ownership of high-value cultural objects, certain knowledge and expertise resulting from formal education, and certificates (Halim, 2014). This cultural capital is embedded in PKH participants in independent graduation called "AY". Since he was a child, he was always interested in cultural activities at the Balai Adat Nagari Office such as randai, piriang dance, payuang dance, knife dance, and martial arts, even he was also involved as a part of these activities. Every week he joined the practice with other friends. Cultural capital he gets from every art and cultural activity. Different things experienced by Suska Putri and "YRS". Where he was directed by his parents to study in Madrasas like the MTsN, and MAN. He believes that with the religious school he can shape a child's personality better. When he became a Nagari activist, for example, he was a member of the Taklim Board and other community groups. When he was a member of the Taklim board, he was very serious in taking care of the religious group until now. Then other different things also experienced by "EE", where he from childhood since always with his parents any Indigenous activities in his tribe, even now he is also active as a traditional leader in his people that is a cando bundo.

\section{d. Symbolic Capital}

Symbolic capital refers to the degree of accumulation of prestige, fame, consecration or honour and is built on dialectics of knowledge and recognition. Bourdieu sees symbolic capital (such as self-esteem, dignity, attention) as a crucial source of power (Hakim, 2016). This is in accordance with what the authors found in $\mathrm{PKH}$ independent graduation participants. Since he was a small PKH participant in his independent graduation, he was always taught to give help to others by giving charity. The giving activity was carried out repeatedly both in the Mosque and Mushalla, as well as outside the house of worship. If someone asks for help, then he gives help. When people ask for alms, he also gives sincerely. This action was carried out according to the ability he had. He admitted that PKH participants graduated independently, what was done became their own pride and satisfaction.

\section{PKH Arena That Role in Encouraging PKH Participants to Independent Graduation}

The arena is a partially autonomous force in which the struggle for positions takes place. In the arena, actors compete for various forms of resources called Bourdieu by Capital. The positions are determined by the form of capital owned by the actors in 
the arena. The aim is to ensure differences that will guarantee the status of social actors (Harker et al., 2009).

a. Monthly Meetings to Add Insights

For independent graduation participants, the group meeting that is held every month is not just to attend the meeting, but to increase their insight. As stated by "WD" and "SP". They are present every month at group meetings diligently without ever taking a break from joining PKH because there are interesting materials obtained by the mentors. The materials provided include how PKH participants can become great parents, they are given material by watching movies, there is Flipchart material that he calls a big picture book, then discussing and lots of toys so that they are not saturated made by PKH companions they. He most often asks even expresses his opinion without being asked to submit an opinion by PKH's companion. A slightly different matter was conveyed by "YRM", he felt helped during the PKH school because he had more understanding about how to care for elderly parents. For "SP", even though he has children who are not yet in school, he remains focused on receiving material delivered by PKH facilitators. He chose to sit at the front and give snacks rather to his children so that he could focus on listening to any material delivered by the program's facilitator.

b. Monthly Meetings as a First Step to Starting a Business

For PKH participants, independent graduation attending group meetings every month is the first step to starting and developing their business. For them, there is a special attraction of household economic material presented by $\mathrm{PKH}$ facilitators. He felt helped by the material because he was taught how to manage household finances, get knowledge about the needs and desires in the household. For them, the material was very helpful for him with a monthly meeting that presented material on opening a household business using small and sustainable capital. When this material is presented he will sit in the front row or near the PKH companion to present the material. He always noted the important points of the material well and listened to the material presented seriously without anyone talking to a friend beside him.

\section{c. Health Checks at Service Facilities}

PKH participant independent graduation such as WD, EE, SP, and AY, he always brings his child to do health checks for toddlers to the Polindes and Puskesmas to immunize, weigh, measure height, provide vitamins, and monitor children's development. Likewise with "YS", he once a month carries out his mother's health check at the Harau District Health Center located in Nagari Taram. He did this to carry out his responsibilities as PKH participants who have elderly family members

d. Noting the presence of children in school

Children participating in the PKH program who do not meet their attendance rate of 85 per cent of effective learning outcomes at their schools, will be reduced by the nominal amount of assistance received by their parents, and some will even be suspended. This was justified by $\mathrm{PKH}$ independent graduation participants that they 
always paid attention to the presence of their school children. They try to keep their children present every day effective school learning because the presence of children at school is one of the conditions to fulfil commitments as PKH participants.

e. Saving to Prepare to Open a Household Business

Saving for PKH participants who are Graduated Mandiri is not just to carry out responsibilities to PKH companions, but saving is saving money to manage PKH fund assistance that goes into the account created by PKH managers to be used as well as possible so that it can be used as a first step to opening a household business. As stated by SP, EE, YRS, WD, and AY. He after receiving PKH assistance, the next day saved 100,000, sometimes up to 250,000 to the PSLA Cooperative. Even when taking PKH aid funds, he never took all PKH assistance into his account, deliberately left in the Savings Bank of 200,000, sometimes up to 500,000. For him, saving is intended to change the life that is passed now and is proven by the amount of money deposited into an existing account. After they feel savings can be taken to be used as capital to open a business, then he will take it and open a business from small to large as the business they are running now. Like "EE" has a used clothing business, "YRS" has a cricket cultivation business, "AY" has a brick hut business, "SP" has a grocery business, and WD has a Breakfast and Grocery business.

\section{f. Open a Home Business}

PKH independent graduation participants like "YRS" choose different household businesses quickly. He dared to start a cultivation business "Sijontu" which started from two boxes to become forty boxes that produced more than five million rupiahs per month. A different attempt was made by "EE", where he chose to open a second clothing business. he started a business by selling from house to house until finally, he set up a modest shop that contained second-hand clothes worth selling. Most of the consumers he visited first to the houses, now many customers shop at the store. Likewise what "AY" did, he chose to open a brick business. Different things are done by "SP" and "WD" who have a grocery business. He opened a business because he often received advice and direction from $\mathrm{PKH}$ facilitators during group monthly meetings. The grocery business that he opened started with a small amount of capital from their savings while he was a PKH member, then after he felt that he was sufficient to start a daily or grocery business. But thanks to his patience and confidence, the business finally developed and could increase the income of the household economy. "WD" informant In addition to selling daily household items he also opened a breakfast business such as rice cake curry, pical, and rice bean porridge, then also sells fried foods such as fried bananas, cassava fries, and fried breadfruit.

g. Utilizing the land around the neighbourhood

Independent graduation participants use the land in their neighbourhood, which is to grow vegetables such as kale, spinach, eggplant, turmeric, chillies, leeks, celadon, tomatoes, bananas, eggplants, and cereals. He planted the plants in the land next to his 
house, then some planted them on vacant land. He planted vegetables and medicinal plants in different ways, namely planted on the ground without using a pot, and using a pot.

PKH participants who graduated independently basically had experiences that influenced attitudes and behaviour. The experience is a value system that was passed since they were small, and teenagers. The value was obtained in family life activities and formal education. Every value is embedded in them and becomes an inseparable part of daily actions and behaviour. This means that internalized experiences cannot be separated from their present behaviour. An example of this can be seen from some of the values found in the field, namely PKH Participants independent graduation tend to have positive values and build both for themselves, and for the family. These values include competence in work, shame, discipline, economical, and honest.

The existence of tenacity in working honed since childhood, for example since childhood they have been accustomed to buying and selling or trading activities, even on a small scale. Although on a small scale these experiences always imprint and are permanently embedded in them. This was indicated by their desire to open businesses facilitated through the PKH program. At every meeting, they always expressed their desire to have a business that could make their lives better. This strong desire is supported by other values that are also contained or owned by them such as shame.

The sense of shame meant that PKH participants did not want to be in the position of people who are pitied and always get help from various parties. This feeling of not wanting to be pitied makes them compelled to always be active and tenacious at work. They want to show that they can live better with the businesses they build

This tenacious attitude at work and shame is also supported by disciplined behaviour, life-saving, and honesty. These values repeatedly become one unity of the value system in $\mathrm{PKH}$ independent graduation participants. This means that habits found in PKH independent graduation participants cannot be released by their desire to any longer be PKH beneficiaries. The experiences of childhood and adolescence carried over and did not change until they were married and became and PKH. As stated by Bourdieu that Habits is social values that are internalized and internalized by individuals, and are manifested into individual actions and behaviour. This value is fixed and unchanging which is created through the process of socialization and lasts a long time. This is in line with the reality of life lived by PKH participants.

The social reality experienced and lived by independent graduation participants shows that they have strong capital. The intended capital is social capital, cultural capital, symbolic capital and economic capital. The four capitals are running, hand in hand or together with each other. Even so, some are formed from quite long processes such as social capital. This capital is formed from the process of PKH participant interaction with individuals, groups and other structures. From the process of interaction that is carried out continuously indirectly has given birth to Trust between 
one another. Continuous interaction, also based on the same values as both have a goal to get out of incompetence. The interaction also gave birth to a network system that would later become the main support of capital to drive economic capital owned by the participants. So that the similarity of values, networks and trust formed will have an impact on improving their welfare. Success in mobilizing social and economic capital naturally influences cultural and symbolic capital. At least the cultural capital is lowered in its genre in the hope that there will be a better chance to the lives of their future children. The process was obtained from efforts to provide more appropriate education and is believed to be a part of making changes. When the education achieved is better, the life or position obtained will be better too. As stated by Bourdieu that Capital (in Harker et al, 2009) is a logic that governs the struggle and strength when in the arena or realm. Each domain or arena requires a person to have special capital in order to live well and survive in it. This capital must be in the arena or domain so that the arena can have meaning or meaning. This capital should be something that must exist and be owned by individuals in their social environment so that it allows people to control themselves and others (Ritzer, 2012).

The Family of Hope Program (PKH) for each participant is a means and facility as well as facilitation that must be utilized as well as possible. Every activity in PKH Arena, participants show and show their respective activities. He wants to appear and be seen by other participants and program managers along with other general public. The way they always attend is every meeting held by the PKH manager, health checks at health service facilities, paying attention to the presence of children at school, saving money, opening a household business, and utilizing the land around his residence for medicinal plants and vegetables. These activities are utilized as well as possible in the hope that the problems they face can be resolved, especially welfare issues. As stated by Bourdieu, that Arena is a power that is partially autonomous and in which the struggle for positions takes place. The positions are determined by the form of capital owned by the actors in the arena. When those positions are reached, the actors who are in the arena will be able to interact with habitus to produce different postures that have a separate effect on taking positions in the realm. This means that the concept of this arena is based on the struggle or competition for certain positions so that the social structure is a dynamic one in which an actor can move from one position to another. The struggle for this position shift, in turn, requires a series of actions or practices that are based on the actor, and are influenced by the agent, as well as what the actor has, including his life history, which is why the actor devises certain strategies (Harker et al., 2009).

\section{CONCLUSION}

Habits who play a role in encouraging participants to independent graduation in $\mathrm{PKH}$ are tenacity in working, have a high sense of shame, discipline, economical, and 
honest. Forms of capital owned by participants of independent graduation at PKH in Lima Puluh Kota Regency are social capital, economic capital, cultural capital, and symbolic capital. PKH Arena which plays a role in the Independent Graduation Participants in PKH in Lima Puluh Kota District, which conducts monthly meetings to broaden horizons, monthly meetings as an initial step to start a household business, conduct health checks at Polindes and Puskesmas, pay attention to the presence of children at school, save for open a household business, dare to open a household business, and use the land around the neighbourhood to grow vegetables and medicinal plants.

\section{REFERENCES}

1. Afrizal. (2014). Metode Penelitian Kualitatif. Jakarta: Raja Grafindo Persada.

2. Andira, A., et al. (2018). Pelaksanaan Program Keluarga Harapan (PKH) dalam Meningkatkan Kesejahteraan Masyarakat di Kecamatan Samarinda Utara Kota Samarinda. Ilmu Pemerintahan Fisip Mulawarman, 6(4).

3. Bakry, O. (2017). Akhlak Muslim. Bandung: Angkasa.

4. Boudieu, P. (2011). Choses Dites: Uraian dan Pemikiran. Yogyakarta: Kreasi Wacana.

5. Casiavera. (2017). Strategi Peserta Program Keluarga Harapan (PKH) Mempertahankan Status Pesertanya (Studi: Nagari Punggasan Timur Kecamatan Linggo Sari Baganti Kabupaten Pesisir Selatan. Tesis. Fakultas Ilmu Sosial dan Ilmu Politik; Universitas Andalas.

6. Daud, M., \& Marini, Y. (2018). Implementasi Program Keluarga Harapan Dalam Meningkatkan Kesejahteraan Masyarakat Miskin. Jurnal Humaniora: Jurnal Ilmu Sosial, Ekonomi dan Hukum, 2(1), 29-38.

7. Field, J. (2010). Modal Sosial. Yogyakarta: Kreasi Wacana.

8. Harker, R., Mahar, C., \& Wilkes, C. (2004). Pengantar Paling Komprehensif kepada Pemikiran Pierre Boerdeou. Yogyakarta: Jalasutra.

9. Haryatmoko, H. (2003). Landasan Teoritis Gerakan Sosial Menurut Pierre Bourdieu; Menyingkap Kepalsuan Budaya Penguasa. Jurnal BASIS, 11(2).

10. Halim, A. (2014). Politik; Pola, Aktor, dan Alur Dramatikalnya. Yogyakarta: LP2B.

11. Karnanta, K. Y. (2013). Paradigma Teori Arena Produksi Kultural Sastra: Kajian Terhadap Pemikiran Pierre Bourdieu. Jurnal Poetika, 1(1).

12. Lubis, A. Y. (2014). Postmodernisme: teori dan metode. Jakarta: Rajawali Pers.

13. Miles, M. B., \& Huberman, M. A. (1992). Analisis Data Kualitatif. Jakarta: University of Indonesia Press

14. Moleong, L. J. (1995). Metodologi Penelitian Kualitatif. Bandung: Remaja Rosdakarya.

15. Muhadjir, N. (1990). Metodologi Penelitian Kualitatif, Telaah Positivitik, Rasionalistik, Phenomenologik, Realisme Metaphisik. Yogyakarta: Rake Sarasin.

16. Mustari, M. (2014). Nilai Karakter Refleksi Untuk Pendidikan. Depok: Raja Grafindo Persada. 
17. Nainggolan, T., \& Susantyo, B. (2018). Upaya Percepatan Penanggulangan Kemiskinan Melalui Program Keluarga Harapan: Studi di Empat Daerah di Indonesia. Sosio Konsepsia, 7(1), 31-46.

18. Restianti, A. (2017). Evaluasi Pelayanan Kesehatan dan Pendidikan Program Keluarga Harapan (PKH). Jurnal Pemberdayaan Masyarakat: Media Pemikiran dan Dakwah Pembangunan, 1(2), 405-426.

19. Ritzer, G., \& Goodman, D. J. (2016). Teori Sosiologi Modern. Jakarta: Kencana Prenada Media Group.

20. Robert, A. (2007). Malu; Sebuah Perspektif Iman. Yogyakarta: Kanisius.

21. Rochani, N. (2011). Pierre Bourdue; Uraian dan Pemikiran. Yogyakarta: Kreasi Wacana.

22. Saptono, B. (2013). Orientasi Modal Sosial dan Modal Kultural di Fakultas Ilmu Pendidikan UNY. Jurnal Penelitian Ilmu Pendidikan, 6(2).

23. Social ministry of the Republic of Indonesia. (2019). Pedoman Pelaksanaan Program Keluarga Harapan. Jakarta: Direktorat Jenderal Perlindungan dan Jaminan Sosial.

24. Suharto, E. (2015). Peran perlindungan sosial dalam mengatasi kemiskinan di Indonesia: studi kasus program keluarga harapan. Sosiohumaniora, 17(1), 21-27.

25. Takwin, B. (2009). Akar-Akar Ideologi Pengantar Kajian Konsep Ideologi dari Plato hingga Bordieu. Yogyakarta: Jalasutra.

26. Virgoreta, D. A. (2015). Implementasi Program Keluarga Harapan (PKH) Dalam Upaya Meningkatkan Kesejahteraan Masyarakat (Studi pada Desa Beji Kecamatan Jenu, Kabupaten Tuban). Jurnal Administrasi Publik, 3(1), 1-6. 